Dept. of Food Hygiene, Animal Health Research Institute, Assiut, Regional Laboratory.

\title{
CHEMICAL AND MICROBIOLOGICAL ANALYSIS TO EVALUATE THE SANITARY CONDITION OF RAW MILK IN ASSIUT
}

(With 3 Tables)

\author{
By \\ EMAN KORASHY and NAHED MOHAMED \\ (Received at 14/5/2008)
}

\section{التحليل الكيميائى والميكروبيولوجى لتقييم الحالة الصحية للبن الخام فى أسيوط إيبان قرشسى ، نـاهد محمد وهبه}

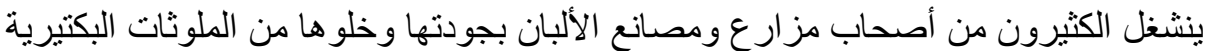

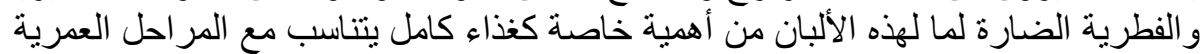

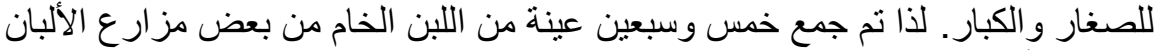

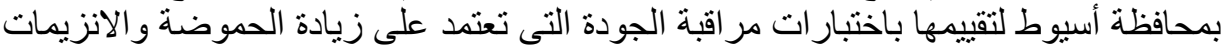

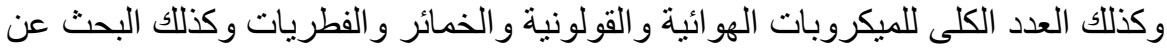

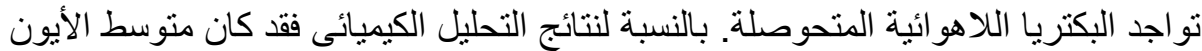

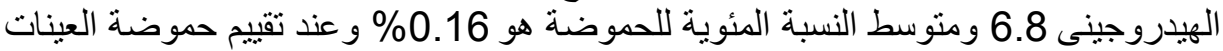

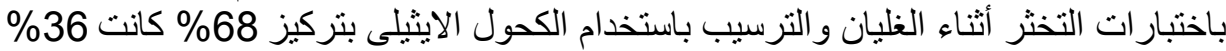

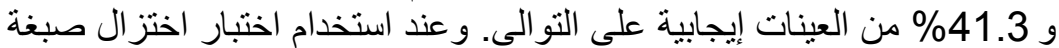

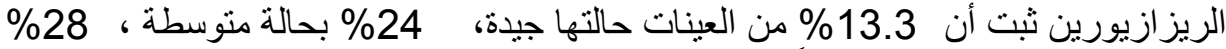

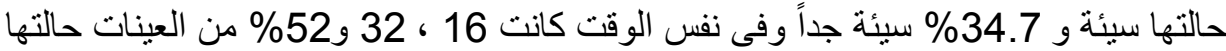

جيدة ، منوسطة وسيئة عند استخدام اختبار الكاتاليز البسيط على التئل التوالى.

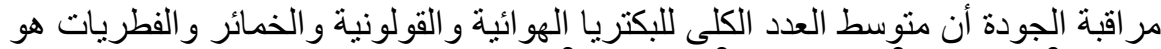

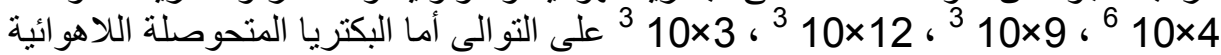

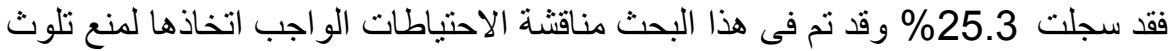

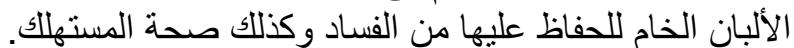

\section{SUMMARY}

Chemical and microbiological analysis were carried out on 75 raw milk samples randomly collected from some dairy farms of Assiut city to evaluate the sanitary condition of raw milk consumed in Assiut. The keeping quality tests which depend on increase amount of acidity revealed an average 6.8 with the $\mathrm{pH}$ value and $0.16 \%$ as acid percentage with the titrable acidity. Clot on boiling and Alcohol precipitation tests 
scored 36 and $41.3 \%$ respectively. The results of keeping quality tests depend on increase amount of enzymes recorded 10 good samples (13.3\%), 8 fair (24\%), 21 bad (28\%) and 26 very bad samples $(34.7 \%)$, with resazurine test. The amount of free oxygen in the simple catalase tube test was 0-2 in 12 good samples (16\%), 2-5 in 24 fair samples (32\%) and was bad in 39 samples (52\%) more than $5 \mathrm{cc}$ free $\mathrm{O}_{2}$. In case of microbiological analysis the averages of total bacterial, coliform, yeast and mould counts were $4 \times 10^{6}, 9 \times 10^{3}, 12 \times 10^{3}$ and $3 \times 10^{3} / \mathrm{ml}$ respectively. Examination for anaerobic spore- formers detected $25.3 \%$ of the examined samples. The public health importance of the counted organisms and the prophylactic measures to improve the quality of dairy farm milk were discussed.

Key words: Sanitary, Chemical, Microbiological, Analysis, raw milk.

\section{INTRODUCTION}

Milk is an important natural food and it exceeds all other foods in the variety and quality of contents with which milk furnishes the human body at all stages of life. So, Prophet Mohamed each time drinks milk calls to Allah to bless milk and to be increased more than other foods.

High quality raw milk free from pathogenic microorganisms, with less than 50,000 microorganisms $/ \mathrm{ml}$ is a growing concern worldwide by the public health authorities, milk industries and consumers due to firstly, the production of high quality dairy products secondly to reduce the significant increase in the incidence of milkborne illnesses (Desmasures et al., 1997).

Milk may be subjected to many risks of contamination from various sources from the time it leaves the udder until it is consumed or manufactured. Milk may become contaminated by small numbers of bacteria from a disease-free udder but the surrounding environment during milk handling and from milk equipments contribute in a high contamination (Thomas et al., 1971 and Cousins and Bramley, 1981). Lack of cooling facilities and high atmospheric temperatures beside the poor hygiene during transportation attribute in lowering the raw milk quality. The raw milk microbial quality is of primary concern to throw light early on the udder which consequently affects the bulk milk appearance, odor, taste and dramatic changes in milk composition and production (Hogan and Smith, 1987 and Sargeant et al., 2001). Several methodologies are used to evaluate the quality control of raw milk. The most important indices of microbiological quality are the total bacterial 
count, coliforms, yeasts, moulds and detection of anaerobics poreformers as recorded by A.P.H.A. (1992). The aerobic plate count was determined by many workers as an index of hygienic measures and sanitary care of equipments, utensils and storage conditions on the farm during milking (Yadava et al., 1985 and Kodikara, 1986). Thus, the dairy regulations in some twons include the total aerobic counts to grade milk for the producer quality-payment scheme.

Coliform as a Gram negative primary pathogen (Harmon, 1994) does not present in udder of dairy animal but in its surroundings (soil, bedding and manure). It is also a normal inhibitant of the intestinal tract of man and animals therefore, coliform count is a part of the microbiological criteria to indicate the hygienic status during milking. Hogan and Smith (1987), pointed out that more than 100 coliform $\mathrm{cfu} / \mathrm{ml}$ indicates the bad hygiene during milking. According to the (W.H.O., 2000) coliforms are responsible for diarrheal disease of $30 \%$ in industrial countries and hundred of millions in developing countries. El-Kosi (2001) obtained higher incidence and counts of coliforms and fecal coliforms from raw milk products.

Fungi including yeasts and moulds are useful as a part of the microbiological analysis to indicate the hygienic status during milking, handling and the storage of milk. They can grow over a wide range of temperatures and gain enterance to raw milk from the contaminated air, dust and utensils. Presence of fungi is of great concern wheather from the public health or economic points of view. Molds are capable of producing toxic secondary metabolites known as mycotoxins causing cases of food poisoning and liver cancer in human (Mossel, 1982). Fungi have probably received more attention by the dairy industries owing to the undesirable changes and defects occurred in milk and milk products under adversity of $\mathrm{pH}$, moisture and temperature leading to down grading of the product (Beuvier et al., 1997). The presence of high counts of these organisms in raw milk is indicative of unsatisfactory sanitation during the milk journey from the time it elapses the udder till reaches to the consumer. Many trials by several examinators were paid to count yeasts and moulds from raw bulk milk (Sabry, 2001, Al-Ganzoury, 2002). Anaerobic sporeformers detection is of great concern to indicate the faecal pollution since, they are normal inhibitant of the lower part of the intestinal tract of worm blooded animals (Smith and Holdeman, 1981) and about $25 \%$ of the human populations excrete the bacteria in their feces (Gudkov and Dolidze, 1975). A complete relation between 
the hygienic production of milk and the presence of the anaerobs. Milk and other dairy products implicated as a cause of Clostridium perfringens food poisoning (Woodward et al., 1970 and Anon, 1982).

Keeping quality tests which include those depend on increase amount of acidity as $\mathrm{pH}$ values, titrable acidity, clot on boiling and alcohol precepitation tests as reported by Lampert (1984) that the acceptable level for titrable acidity of fresh raw milk is $0.12-0.16 \%$. While, those depend on increase amount of enzymes as resazurine and catalase tests together with microbiological analysis were found to be reliable indices to evaluate the sanitary conditions under which milk have been produced and handled (Garvie and Rowlands, 1952; Nakae et al., 1978; Yadava et al., 1985 and Kodikara, 1986). Therefore, the production of high quality milk should be a priority and of great importance to the economy of the dairy farms and the sustainable development of the dairy industry.

A considerable amount of research has been devoted on the study of the sanitary condition of raw milk by many workers and several authors at different countries (El-Leboudy et al., 1992; Harmon, 1994; El-Shinawy et al., 1995; Desmasures et al., 1997 and Sabry, 2001).

This preliminary study was planed to evaluate the sanitary condition of raw milk of some dairy farms in Assiut city by applying the following keeping quality tests:

1- Tests depend on increase amount of acidity including:

- $\mathrm{pH}$ value

- Titrable acidity

- Clot on boiling and alcohol precipitation

2 - Tests depend on increase amount of enzymes including:

- Resazurine

- Simple catalase test

3 - Microbiological examination to determine:

- Total bacterial counts

- Coliform count

- Yeast and mould counts

- Detection of anaerobs.

\section{MATERIAL and METHODS}

Seventy five raw milk samples were collected randomly and aseptically in screw-cap bottles from some of Assiut city dairy farms. Samples were transferred to the laboratory in Harare as possible and 
stored at $4{ }^{\circ} \mathrm{C}$ until analysis that began within $24 \mathrm{hrs}$ of sampling. Milk samples were tested by Storch test according to Lampert (1975) to exclude the heat treated milk samples.

\section{Chemical analysis:}

1- Keeping quality tests depend on increase amount of acidity:

- $\mathrm{pH}$ value according to (APHA, 1992). Using electrical digital $\mathrm{pH}$ meter (an Orion Model).

- Titrable acidity according to (Case et al., 1985).

- Clot on boiling and alcohol precipitation tests were applied according to (APHA, 1992).

2- Keeping quality tests depend on increase amount of enzymes adopted according to (APHA (1992) and Chalmers, 1992). Resazurine and Catalase tube test.

\section{Microbiological analysis:}

Total bacterial counts: by applying the standard plate count technique according to APHA (1992).

Coliform count: using Violet Red Bile agar (FAO, 1992) as recommended by Mercuri and Cox (1979).

Total yeasts and moulds count: according to Harrigan and McCance (1976) using Sabaroud Dextrose agar (Difco Lab.).

Anaerobic sporeformers: by stormy fermentation test according to Cruickshank et al. (1969).

\section{RESULTS}

The obtained results were tabulated in Tables 1-3.

Table 1: Statistical analytical results of keeping quality tests depend on increase amount of acidity of the examined raw milk samples.

\begin{tabular}{|c|c|c|c|c|c|c|}
\hline Parameter & $\begin{array}{c}\text { No. of } \\
\text { examined } \\
\text { samples }\end{array}$ & Min & Max. & Average & \multicolumn{2}{|c|}{$\begin{array}{c}\text { +ve samples above } \\
\text { acceptable level } \\
(0.12-0.16 \%) \\
\text { Lampert, } 1984\end{array}$} \\
\hline \multirow{2}{*}{$\begin{array}{c}\mathrm{pH} \\
\text { Titrable acidity }\end{array}$} & \multirow{4}{*}{$\begin{array}{l}75 \\
75\end{array}$} & 6.7 & 6.9 & \multirow{2}{*}{$\begin{array}{c}6.8 \\
0.16\end{array}$} & $\mathrm{No} / 75$ & $\%$ \\
\hline & & 0.12 & 0.18 & & $\begin{array}{l}39 \\
36\end{array}$ & $\begin{array}{l}52 \\
48\end{array}$ \\
\hline & & \multicolumn{3}{|c|}{ No. of $+v e / 75$} & \multicolumn{2}{|c|}{$\%$} \\
\hline $\begin{array}{l}\text { Clot on boiling test } \\
\text { Alcohol precipitation test }\end{array}$ & & \multicolumn{3}{|c|}{$\begin{array}{l}27 \\
31\end{array}$} & \multicolumn{2}{|c|}{$\begin{array}{c}36 \\
41.3\end{array}$} \\
\hline
\end{tabular}


Table 2: Statistical analytical results of keeping quality tests depend on increase amount of enzymes of raw milk samples.

\begin{tabular}{|c|c|c|c|c|c|c|c|c|}
\hline \multirow{2}{*}{$\begin{array}{c}\text { Total No. } \\
\text { of } \\
\text { samples }\end{array}$} & \multicolumn{4}{|c|}{ Resasurine test } & \multicolumn{3}{c|}{ Simple catalase test } \\
\cline { 2 - 8 } & Grade & Color & $\begin{array}{c}\text { No. } \\
\text { of } \\
+ \text { ve }\end{array}$ & $\%$ & Grade & $\begin{array}{c}\text { Amount } \\
\text { of } \mathrm{O}_{2}\end{array}$ & $\begin{array}{c}\text { No. } \\
\text { of } \\
+ \text { ve }\end{array}$ & $\%$ \\
\hline \multirow{4}{*}{75} & Good & Blue violet & 10 & 13.3 & Good & $0-2$ & 12 & 16 \\
& Fair & Red violet & 18 & 24 & Fair & $2-5$ & 24 & 32 \\
& Bad & Red & 21 & 28 & Bad & $\begin{array}{c}\text { More } \\
\text { than 5 }\end{array}$ & 39 & 52 \\
& V. bad & Colorless & 26 & 34.7 & & & \\
\hline
\end{tabular}

Table 3: Statistical analytical results of different types of organism counts of raw milk samples.

\begin{tabular}{|c|c|c|c|c|c|c|c|}
\hline \multirow[t]{2}{*}{$\begin{array}{l}\text { Type of } \\
\text { organism }\end{array}$} & \multirow[t]{2}{*}{$\begin{array}{l}\text { No. of +ve } \\
\text { samples/75 }\end{array}$} & \multirow[t]{2}{*}{$\%$} & \multirow[t]{2}{*}{ Min. } & \multirow[t]{2}{*}{ Max. } & \multirow[t]{2}{*}{$\begin{array}{l}\text { Average of } \\
\text { +ve samples }\end{array}$} & \multicolumn{2}{|c|}{$\begin{array}{l}\text { +ve samples } \\
\text { above the EOS } \\
\text { (2001) }\end{array}$} \\
\hline & & & & & & No. & $\%$ \\
\hline T.C.C. & 75 & 100 & $1 \times 10^{4}$ & $2.8 \times 10^{8}$ & $4 \times 10^{6}$ & 28 & 37.3 \\
\hline Coliform & 31 & 41.3 & $>\times 10^{2}$ & $2 \times 10^{5}$ & $9 \times 10^{3}$ & 24 & 32 \\
\hline Yeast & 61 & 81.3 & $>10^{2}$ & $8 \times 10^{5}$ & $12 \times 10^{3}$ & - & - \\
\hline Mould & 49 & 65.3 & $>10^{2}$ & $8 \times 10^{4}$ & $3 \times 10^{3}$ & - & - \\
\hline $\begin{array}{c}\text { Anaerobic } \\
\text { spores }\end{array}$ & 19 & 25.3 & - & - & - & - & - \\
\hline
\end{tabular}

\section{DISCUSSION}

A wide spread concern with increasing focus on the milk quality on dairy farms and dairy industries was noticed in recent years to safeguard consumers and to be a priority of establishment of strong market for milk and milk products.

Although the quality control tests measured the activity of organisms present in the examined samples in Table 1 showed that the average value of $\mathrm{pH}$ and the acidity percentage by titrable acidity was $6.8 \%$ and $0.16 \%$ respectively, $39(52 \%)$ and $36(48 \%)$ of the examined samples were above the acceptable limit recorded by Lampert (1984) and consequently they were unfit for heat treatment, processing and human consumption. El-Leboudy et al. (1992) and Sabry (2001) scored lower results than that obtained, while higher values were obtained by Mutukumira et al. (1996). Determination of $\mathrm{pH}$ value is an effective predictor of instability in the end product and is the most useful made on the milk after bulk storage as it indicates its real acidity. 
Although titrable acidity expressed as lactic acid in milk. Al-Ashmawy (1990) prefered the $\mathrm{pH}$ value than the titrable acidity and considered it as less variable. Following up the keeping quality tests depending on increase amount of acidity, Table 1 indicated that 27 (36\%) and $31(41.3 \%)$ of the samples were sour and unfit for heat treatment with clot on boiling and alcohol precipitation tests, respectively. Alcohol precipitation test is more sensitive than clot on boiling test since it gives positive results with colostrum, mastitic milk due to E. coli and sweet curdling due to rennin like enzyme produced by the aerobic spore formers. It is useful for determination of the stability of milk to evaporation and sterilization by heat. It was observed during this study that the $\mathrm{pH}$ values and the concentration of titrable acidity of some of the samples suggested that the raw milk had started souring when samples were collected hence, milk was subjected to high temperatures which may have led to rapid multiplication of microorganisms resulting in souring of the milk samples.

In Table 2 resazurine test which is based on the reduction of a dye to a colorless compound by metabolic activities of bacteria indicated that 13.3, 24, 28 and $34.7 \%$ of the samples graded good, fair, bad and very bad, respectively. The results were not in accordance with Sabry (2001) and Al-Ganzoury (2002). They were in agreement with El-Leboudy et al. (1992) who graded 58.3 and $52.5 \%$ of inferior quality cow's and buffalo's milk samples with Methylene blue reduction test, respectively. Reduction tests are considered by several authors as indicative for the sanitary conditions under which milks were produced Garvie and Rowlands (1952), while, Resazurine test is considered a rapid and simple method for grading milk.

Results of simple catalase tube test in Table 2 revealed that 39 $(52 \%)$ of the examined samples were of bad quality and should be rejected as the amount of free oxygen was more than $5 \mathrm{CC}$ and the results were disagreed with Al-Ganzoury (2002). Only, 12 (16\%) and 24 (32\%) of the samples graded good and fair, respectively. Catalase tests depend on the amount of catalase enzyme, which present normally in milk but in little amount. So, they are used to detect the abnormal milk based upon somatic cell contents which accelerate the decomposition of $\mathrm{H}_{2} \mathrm{O}_{2}$ by catalase enzyme.

Concerning the microbiological analysis, Table 3 cleared that the raw milk samples examined were positive for the standard plate $(100 \%)$ and the total aerobic counts ranged between $1 \times 10^{4}$ and $2.8 \times 10^{8} \mathrm{cfu} / \mathrm{ml}$ 
with an average $4 \times 10^{6}$. Nearly similar results were obtained by El-Leboudy et al. (1992), El-Shinawy et al. (1995), Mutukumira et al. (1996) and Abdel Moghney et al. (2001). The results were higher than Desmasures et al. (1997) and Al-Ganzoury (2002). High total aerobic count is usually used to assess the overall sanitation and storage condition of the raw milk. Marshall (1982) and Muir et al. (1986) reported that the high total aerobic count not only lead to bad quality of raw milk but also quality defect in milk products.

According to the Egyptian Standard (EOS, 2001) and the British one (Thomas and Thomas, 1975) which pointed out that more than $2 \times 10^{5}$ bacteria/ml have poor quality it was obvious that $28(37.3 \%)$ of the examined samples were above the Egyptian and the British Standards. Therefore, the obtained results of the examined dairy farm milk samples were of poor quality and that reflects the sanitary conditions adopted on the farms during milking, handling, storage and transportation. The variation in results of the total bacterial counts may be linked to the alternative use of alkaline and acid detergents during milking process (Chatelin and Richard, 1983). The giving results in Table 3 showed that $31(41.3 \%)$ of the examined raw dairy farm milks have an average count of coliform $9 \times 10^{3} / \mathrm{ml}$. Different results obtained by the same above mentioned specialists. According to the EOS (2001) which pointed out that the limited count by coliform was 100 coliform cells and less than 1000 cells $/ \mathrm{ml}$ of milk, the result obtained included 24 (32\%() samples were above the limited Egyptian Standard and only 5 samples were within the limited standard. Therefore, presence of large numbers of coliform bacteria in raw milk provides an index of the hygienic standards used during the production of milk. Public health concern intended for coliform especially in children who subjected to certain cases of gastroenteritis when intended for liquid utilization of not heat treated milk (Cruickshank et al., 1984). Coliforms incriminated in food poisoning and cases of cystitis and pyelonephritis (Finegold and Martin, 1982). Approximately 70 to $80 \%$ of coliform infections give clinical or systemic symptoms of mastitis (Harmon, 1994). Coliforms also have economic importance for the disgrading of the milk value affecting the economic condition of the dairy plant through milk and milk products spoilage including acid production, sliminess, ropiness, bitter and soapy flavours, grassy unclean fecal odor (Stead, 1986). During the course of the microbiological analysis of the samples yeasts and moulds were predominant. They revealed 61 (81.3) and 49 (65.3\%) 
with averages $12 \times 10^{3}$ and $3 \times 10^{3} / \mathrm{ml}$ respectively. The results did not agree the findings by several examinators who could not detect yeasts and moulds from raw bulk milk (Hussain et al., 1984; El-Rashidy, 1986; El-Kholy et al., 1994 and Mutukumira et al., 1996). The results were higher than that obtained by Desmasures et al., 1997 and Al-Ganzoury, 2002. Presence of yeasts and moulds in raw milk is indicative for the neglected sanitation during the milking process. Presence of yeasts and moulds in raw milk is of great concern not only to the health of human and animals due to the mycotoxins production which responsible for food poisoning and liver cancer in human (Mossel, 1982), but also they can cause lipolytic and proteolytic spoilage which influence the biochemical characters and flavour of the product and commercially be undesirable and down grading (Beuvier et al., 1997).

From Table 3 the anaerobic sporeformers bacteria revealed 19 (25.3\%). They are higher than that obtained by Abdel-Hakeim (1992) and some what near to Desmasures et al. (1997). Other investigators could isolate the organism from milk and other milk products El-Bassiony (1980) and Saad (1995). The presence of the anaerobic bacteria in milk is indicative for the neglected sanitary measures during production and distribution since the organism is more widely distributed than any other pathogenic bacteria occurring in soil, dust and among the intestinal microflora of warm-blooded animals (Smith and Holdeman, 1981) and so, it is considered as one of feacal contaminants (Romagnoli and Brazzi, 1960). Anaerobic sporeforms bacteria have the ability to release toxin in the alimentary canal after ingestion of contaminated food (8-15 hs) causing foodborne illness $15 \mathrm{~h}$, also they are accepted as an etiological agent of gas gangarene in man and animals (Hobbs, 1965) and acute mastitis (Johnston, 1986). Milk and other dairy products incremenated as a cause of clostridium food poisoning (Woodward, 1970 and Anon, 1982)

It is worth to mention that considerable variations in the microbial content of the raw examined dairy farm milk samples were noticed during the microbiological analysis and this may be attributed to the hygienic standard during milking and storage facilities adopted in each dairy farm. It was obvious that the most raw milk contaminations were yeasts than bacteria to ensure the neglected sanitation adopted.

The microbiological, and chemical properties of raw milk are the basis for the high quality milk and milk products. Therefore, sanitary control measures including the hygienic condition of the animal, milkers 
and equipments used for milking should be adopted during production, handling and storage of milk, beside the applying of the quality control tests from time to time to grade dairy farm milks.

\section{REFERENCES}

Abdel-Hakiem, H.E. (1992): Incidence and public health importance of some food poisoning organisms in milk and some dairy products. M.V.Sc. Thesis, Faculty of Veterinary Medicine, Suze Canal University.

Abdel Moghney, A.F.; Abozahra, A.A. and Nasser, M.N.H. (2001): Risk factor of water pollution on mastitis and milk souring in dairy farms. Assiut Vet. Med. J. Vol. 44, No. 88, January.

Al-Ashmawy, A.M. (1990): Food Hygiene Handbook. Fluid milk, dairy products, fats and oils and eggs. Fac. Vet. Med., Zagazig Univ.

Al-Ganzoury, H.H. (2002): Chemical and Microbiological Quality of Ewes Milk. SCVMJ, V (1) 43-50.

American Public Health Association (APHA) (1992): Standard Methods for Examination of dairy products. INC., $16^{\text {th }}$ Ed. New York.

Anon, A. (1982): Diseases attributed to dairy products. Brit. Med. J. 285: 1664-1669.

Beuvier, E.; Berthaud, K.; Cgarra, S.; Dasen, A.; Pochet, S.; Buscihon, S. and Duboz, G. (1997): Ripening and quality of Swiss-type cheese made from raw, pasteurized or microfiltered milk. Inter. Dairy J. 7: 311-323.

Case, R.A.; Bradley, J.R. and Williams, R.R. (1985): Chemical and physical methods, p. 327-404. In G.H. Richardson (ed), Standard methods for the examination of dairy products. $15^{\text {th }}$ ed American Public Health Association, Washington D.C.

Chalmers, C.A. (1992): Bacteria in relation to the milk supply. Edward Arnold (Publisher), London, LTD.

Chatelin, Y.M. and Richard, J. (1983): Comparaison, dans des conditions courantes, de l'efficacité de quatre methods de nettoyage des machines à traire. Lait 63, 87-101.

Cousins, C.M. and Bramley, A.J. (1981): The microbiology of raw milk, p. 119-163. In R.K. Robinson (ed). Dairy microbiology, Vol. 1 Applied Science Publishers, U.K.

Cruickshank, R.; Duguid, J.P. and Swain, R.H. (1969): Medical Microbiology $11^{\text {th }}$ Ed. E.S. Livingston Limited Edinburgh, London. 
Cruickshank, R.; Duguid, J.P.J.; Marinion, B.P. and Swain, R.H.A. (1984): Medical Microbiology $12^{\text {th }}$ Ed. Vol. 11 Churchill Livingstone Edinburgh, London and New York.

Desmasures, N.; Bazin, F. and Gueguen, M. (1997): Microbiological composition of raw milk from selected farms in the Camembert region of Normandy. Journal of Applied Microbiology 83, 53-58.

Egyptian Organization for Standardization and Quality Control "EOS" (2001): Milk No. 54. Ministry Industry and Mineral Wealth, Cairo, Egypt.

El-Bassiony, T.A. (1980): Occurrence of Clostridum perfringens in milk and dairy products. J. Food Protection. 43, 7: 536-537.

El-Kholy, A.M.; Hosein, H.I. and Thabet, A.El-R. (1994): Chemical and cytobacteriological studies for detection of subclinical mastitis. Assiut Vet. Med. J. Vol. 30, No. 60, January.

El-Kosi, O.H. (2001): Occurrence of some enteric pathogen and their indicators in some Egyptian raw milk products. Assiut Vet. Med. J. 45: 48-61.

El-Leboudy, A.A.; Nazem, A.M. and Al-Hawary, I.I. (1992): Microbial monitoring of dairy plant milk. Alex. J. Vet. Sci., Vol. 8, No. 1, November 1992.

El-Rashidy, A.A. (1986): Screening and confirmatory methods for detection of abnormal milk. Ph.D. Thesis, Fac. Vet. Med., Alex. Univ.

El-Shinawy, S.H.; El-Kholy, A.M. and Abd El-Gwad, M.H. (1995): Sanitary condition of market raw milk in Beni-Suef Governorate. Beni-Suef, Vet. Med. Res. Vol. V, No. 1, January. FAO, Food and Agriculture Organization (1992): Manual of Food Quality Control. 4, Rev. I Microbiological analysis Washington, D.C.

Finegold, S.M. and Martin, W.F. (1982): Bailey and Scotts. Diagnostic Microbiology. $6^{\text {th }}$ Ed. pp. 1999. The C.V. Mosby Co. St. Louis, Toronto, London.

Garvie, E.I. and Rowlands, S.A. (1952): The role of microorganisms in dye reduction and keeping quality tests. II- The effect of microorganisms when added to milk in pure and mixed culture. J. Dairy Res. 19, 263. 
Gudkov, A.V. and Dolidze, G.G. (1975): Microbiological incidence of the quality of milk for cheese manufacture, Molochnaua promyshlennost, No. 2: 15-19. Dairy Sci. Abst. 37, 1 (1976).

Harmon, R.J. (1994): Mastitis and genetic evaluation for somatic cell count, physiology of mastitis and factors affecting somatic cell count. J. Dairy Sci., 77: 2103-2112.

Harrigan, W.F. and McCance, E. (1976): Laboratory Methods in Food and Dairy Microbiology. Academic Press In London Ltd.

Hobbs, B.C. (1965): Clostridium welchii as a food poisoning organism. J. Appl. Bact. 28: 74-79.

Hogan, J.S. and Smith, K.L. (1987): A practical look at environmental mastitis. Comp. Continuing Educ. Pract. Vet. 9: F 341.

Hussain, M.: Naeem, K. and Jobal, N. (1984): Subclinical mastitis in cows and buffaloes identification and drug susceptability of causitive organisms. Pakistan Veterinary J., 4 (3): 161-164.

Johnston, A.M. (1986): A successfully treated, cases of mastitis in the bovine associated with Clostridum perfringens type A. Vet. Record, 118: 728-729.

Kodikara, C.P. (1986): A study of bacteriological and keeping qualities of raw milk. Srilanka Vet. J. 34 (1-2) 9-15. Dairy Sci. Abst. 51 (4): 101.

Lampert, L.M. (1975): Modern Dairy Products $3^{\text {rd }}$ ed., Chemical Publishing Company, Inc., New York, USA.

Lampert, L.M. (1984): Modern Dairy Products $3^{\text {rd }}, 2^{\text {nd }}$, printing, Chemical Publishing Company, Inc., New York, USA.

Marshall, R.T. (1982): Relationship between the bacteriological quality for raw milk and the final products. A review of basic information and practical aspects. Kieler Milchwirts Forschungsber. 34: 149-157.

Mercuri, A.J. and Cox, N.A. (1979): Coliform and Enterobacteriacae isolates from selected foods. J. Food Prot., 42 (9): 712.

Mossel, D.A.A. (1982): Microbiology of foods $3^{\text {rd }}$ Ed. The University of Utrech., the Netherlands. ISBN.

Muir, D.D.W.; Griffiths, W.M.; Phillips, J.D.; Sweetsur, A.W.M. and West, I.G. (1986): Effect of bacterial quality of raw milk on bacterial quality and some other properties of low heat and high heat dried milk. J. Soc. Dairy Technol., 39: 115-118.

Mutukumira, A.N.; Feresu, S.B.; Narvh, J.A. and Abrahamsen, R.K. (1996): Chemical and Microbiological quality of raw milk 
produced by small holder farmers in Zimbawe. Journal of Food Protection, Vol. 59, No. 9, p. 984-987.

Nakae, T.; Katoaka, K.; Miyamoto, T. and Kondo, A. (1978): The quality of raw milk produced in Okayama, Pretecture-chemical composition. Scientific Report of the Faculty of Agriculture. Okayama Univ. No. 51, 27-62. Dairy Sci. Abst. 41, 5356.

Romagnoli, G. and Brazzi, G. (1960): Faecal contamination and presence of sulphite reducing clostridia. Riv. Ital. Ig. 20: 48-52. Dairy Sci. Abs. 23, 3 (1961).

Saad, N.M. (1995): Incidence of Clostridum perfringens in milk powder. Assiut Veterinary Medical Journal. V. 32, No. 64, 151, January 1995.

Sabry, Y.M. (2001): Thermoduric Psychrotrophic Bacteria in Milk and some Dairy products. M.V.Sc. (Milk Hygiene) Faculty of Veterinary Medicine, Assiut University.

Sargeant, J.M.; Leslie, K.E.; Shirley, J.E.; Pulkrabet, B.J. and Lim, G.H. (2001): Sensitivity and specificity of somatic cell count and California mastitis test for identifying intra mammary infection in early lactation. J. Dairy Sci. 84: 2018-2024.

Smith, L.D. and Holdeman (1981): The pathogenic anaerobic bacteria. pp. 203. Springfield Illinois. Charles C. Thomas.

Stead, D. (1986): Microbial lipase-their characteristic role in food spoilage and industrial uses. J. Dairy Res. 53: 481-505.

Thomas, S.B.; Druce, R.G. and Jones, M. (1971): Influence of production conditions on the bacteriological quality of refrigerated from bulk milk-a review. J. Appl. Bacteriol. 34: 659-677.

Thomas, S.B. and Thomas, B.F. (1975): The bacteriological grading of bulk collected milk. Dairy Ind. J. 40: 478-480.

WHO, World Health Organization (2000): Surveillance programe for control of food borne infection and intoxication in Europe. Newsletter, No. 63 March 2000.

Woodward, W.E.; Grangarosa, E.G.; Brachman, P.S. and Curlin, G.T. (1970): Foodborne disease surveillance in the United States. Amer. J. Publ. Health. 60: 139-137.

Yadava, R.; Choudhary, S.P. and Narayan, K.G. (1985): Bacterial flora of market milk and its public health importance. Indian J. Dairy Sci. 38 (3): 235-236. 